\title{
"Um vasto prazer, quieto e profundo"1
}

\author{
ELIANE ROBERT MORAES
}

1

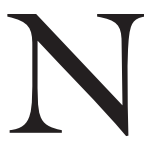
O PRIMEIRO parágrafo, os personagens já são dados como mortos. Mortos e enterrados, sublinha o narrador logo de início, como que desafiando uma certa ideia de "história" que inspira as práticas mais convencionais de leitura. Afinal, expor o desfecho antes mesmo de apresentar a trama pode levar um texto literário à ruína, sobretudo se ele estiver nas mãos de um leitor tradicional. Apesar disso, Machado de Assis insiste em se valer de um tal expediente - como já fizera em As memórias póstumas de Brás Cubas - para abrir o conto "A causa secreta", publicado originalmente em 1885.

Também nesse caso, mas por razões distintas do romance de 1880, trata-se de uma história que não poderia ser desenterrada se os seus protagonistas ainda estivessem vivos. A se crer no narrador, era preciso deixar passar o tempo e guardar distância do ocorrido para que os fatos pudessem enfim ser rememorados. E mesmo assim, anos depois, quando ele se dispõe a reanimar os personagens para "contar a história sem rebuço", resta na paisagem um forte odor de morte.

Não é outra a impressão de quem acompanha as primeiras frases do conto, que introduzem ao leitor os três protagonistas, antes mesmo de informar que eles já deixaram o mundo dos vivos. A cena, passada na sala de visitas de uma casa burguesa do Catumbi, prima sobretudo pela disposição glacial: "Garcia, em pé, mirava e estalava as unhas; Fortunato, na cadeira de balanço, olhava para o teto; Maria Luísa, perto da janela, concluía um trabalho de agulha. Havia já cinco minutos que nenhum deles dizia nada" (Assis, 1998, p.287). A imagem se organiza a partir de figuras francamente funestas: silêncio, imobilidade, solidão.

A descrição sucinta e o tom seco do relato reforçam a atmosfera letárgica que pesa sobre os convivas da desalentada reunião, sugerindo um estranho afrouxamento das forças vitais. Os movimentos mínimos que atestam a presença de Garcia, Fortunato e Maria Luísa carecem de vigor. Nesse sentido, não seria descabido comparar a cena machadiana ao espetáculo lento e progressivo de catatonia que Bachelard (1989, p.19) diagnostica no protagonista de A metamorfose, interpretando-o como um "retardamento da vida". Ao observar que o psiquismo de Gregor Samsa se encolhe ao longo do romance para dar lugar a um estado de impotência que prenuncia a morte, o filósofo conclui: "as formas empobrecem em Kafka porque o querer-viver vai se esgotando". 
Machado também associa o clima de desânimo do trio a uma perda de energia que se traduz no plano formal. Com efeito, para compor a cena, pontuada pelos gestos insignificantes e automáticos dos personagens, o escritor parece lançar mão de uma arte menor, ou ao menos pouco vigorosa, que é o quadro vivo. Paradas e quietas, as três figuras apáticas do parágrafo inicial se oferecem ao olhar do leitor na condição de um objeto pictórico: subordinado a um enquadramento fixo, o grupo disposto naquela tensa sala de visitas compõe uma imagem tão austera quanto inerte.

O quadro vivo é, de certo modo, um teatro sem ação. Elemento popular da cultura europeia desde a Idade Média, as imagens formadas por pessoas estáticas serviram durante muito tempo a propósitos religiosos, representando presépios e martírios, dentre os quais a Paixão de Cristo ganhou particular destaque. Essa forma de espetáculo manteve sua popularidade até o final do século XIX quando, para além dos dramas litúrgicos, passou também a representar cenas profanas, atendendo às demandas do divertimento burguês. Roland Barthes (1979, p.150) lembra que, a partir de então, o quadro vivo tornou-se igualmente um jogo mundano, não raro propondo desafios análogos ao da charada. Não se pode ficar alheio a esse sentido quando se recorda o título do conto em questão.

Ora, cumpre interrogar, qual é a charada proposta por meio desse quadro que se impõe ao leitor já na primeira página do conto?

Para responder à pergunta, é preciso revisitar a tal passagem, avançando um pouco no relato:

Garcia, em pé, mirava e estalava as unhas; Fortunato, na cadeira de balanço, olhava para o teto; Maria Luísa, perto da janela, concluía um trabalho de agulha. Havia já cinco minutos que nenhum deles dizia nada. Tinham falado do dia, que estivera excelente, - de Catumbi, onde morava o casal Fortunato, e de uma casa de saúde, que adiante se explicará. [...] Tinham falado também de outra coisa, além daquelas três, coisa tão feia e grave, que não lhes deixou muito gosto para tratar do dia, do bairro e da casa de saúde. Toda a conversação a este respeito foi constrangida. Agora mesmo os dedos de Maria Luísa parecem ainda trêmulos, ao passo que há no rosto de Garcia uma expressão de severidade, que não lhe é habitual. Em verdade, o que se passou foi de tal natureza, que para fazê-lo entender, é preciso remontar à origem da situação. (Assis, 1998, p.287)

Não resta dúvida de que o trecho se estrutura a partir de um segredo. A disposição dos personagens na cena muda evoca aquela "eloquência do silêncio" que Bentinho associa a Capitu quando ambos se veem diante da mãe dele, na sala de visitas, tentando dissimular os sentimentos recém-declarados. Já na sala de Fortunato, é a gramática do olhar que fala mais alto: enquanto o dono da casa fixa sua mirada no teto, Garcia e Maria Luísa baixam os olhos, em atitude que insinua temor ou, ao menos, obediência. $\mathrm{O}$ desencontro de olhares entre os três protagonistas anuncia as posições que cada qual vai ocupar na história, deixando claro quem tem ascendência sobre quem. 
É evidente também que o segredo diz respeito à misteriosa casa de saúde, sobre a qual "adiante se explicará", e sobretudo àquela "coisa tão feia e grave" que não pode ser nomeada, ou talvez, de tão sinistra, nem venha mesmo a ter um nome. Como bem observa Silviano Santiago (no prelo), que se refere a essa passagem como "cinco minutos de silêncio", o conto "ata a casa de saúde à 'outra coisa', sem desatá-las, para enunciar comprometedoramente a primeira como origem do segredo que se anuncia pelo lado daninho". Assim, completa o crítico, "a coisa é anunciada e logo tem a explicitação de conteúdo retardada" (ibidem). ${ }^{2}$

Isso sugere que o quadro vivo cumpre perfeitamente a tarefa de introduzir a charada, dada a clareza com que dispõe os elementos em jogo, mas não avança em termos de seu desvendamento. Embora seja um expediente eficaz na exposição do enigma, é por certo insuficiente para engendrar os meios de sua decifração. Tal como uma paisagem de árvores mortas, a cena congelada se insinua como pura representação, alheia à dinâmica do tempo e da própria narração. Tendo sido devidamente fixada, iluminada e enquadrada, a imagem da trinca na sala do casal Fortunato fica irremediavelmente aprisionada pelo discurso descritivo. Tudo leva a crer que o conhecimento da coisa em questão depende da passagem do quadro vivo à cena viva.

De fato, para que o mistério da casa do Catumbi venha à tona, o mero enquadre deve ceder lugar ao ato teatral. A imagem estática deve ser substituída pela cena em movimento. Se, naquela, o que funcionava era uma espécie de "máquina sem sujeito" - cujos personagens, limitados a gestos mínimos e automáticos, ocupavam posição análoga à de um mecanismo -, nesta o que vai contar é o vigor emprestado à ação. Passa-se da figura ao funcionamento. $\mathrm{Ou}$, se quisermos colocar nos termos de Roland Barthes (1979, p.151): "passa-se da representação ao trabalho". Vamos a ele.

\section{2}

A trama é aparentemente simples. ${ }^{3}$ Nas poucas páginas que separam o quadro inicial da cena fatídica, o leitor acompanha em flashback os passos que vão reunir em definitivo os três personagens. Garcia, ainda estudante de medicina, topa com Fortunato em três ocasiões distintas mas pontuadas por imagens de sofrimento alheio com as quais, de alguma forma, ambos se envolvem. Mais tarde, voltam a se encontrar e iniciam uma amizade alicerçada pelas novas condições que cada qual ostenta: o médico recém-formado passa a frequentar a casa do capitalista e de sua jovem esposa, Maria Luísa, que lhe inspira intensa ternura. As afinidades se multiplicam, associando os afetos aos interesses: Garcia sublima seus sentimentos pela moça, ganha a intimidade do casal e se torna sócio de Fortunato em uma clínica de saúde.

Conforme o enredo avança, porém, uma suspeita toma corpo, abalando a relação do trio. Sob as vistas de Garcia, a instável Maria Luísa dá mostras cada vez mais fortes de que há algo de errado naquela casa, mas o jovem médico pa- 
rece resistir a todas as evidências até o momento em que é obrigado a encarar uma prova incontestável do tal "erro". Isso ocorre quando a jovem, em estado de pânico, o conduz ao gabinete particular do marido e Garcia testemunha o deleite do sócio ao se abandonar a uma de suas habituais práticas como "médico amador". É nesse ponto da narrativa que o texto se abre à irrupção de um trabalho.

Viu Fortunato sentado à mesa, que havia no centro do gabinete, e sobre a qual pusera um prato com espírito de vinho. O líquido flamejava. Entre o polegar e o índice da mão esquerda segurava um barbante, de cuja ponta pendia o rato atado pela cauda. Na direita tinha uma tesoura. No momento em que o Garcia entrou, Fortunato cortava ao rato uma das patas; em seguida desceu o infeliz até à chama, rápido, para não matá-lo, e dispôs-se a fazer o mesmo à terceira, pois já lhe havia cortado a primeira. Garcia estacou horrorizado.

- Mate-o logo! disse-lhe.

- Já vai.

E com um sorriso único, reflexo de alma satisfeita, alguma coisa que traduzia a delícia íntima das sensações supremas, Fortunato cortou a terceira pata ao rato, e fez pela terceira vez o mesmo movimento até a chama. O miserável estorciase, guinchando, ensanguentado, chamuscado, e não acabava de morrer. Garcia desviou os olhos, depois voltou-os novamente, e estendeu a mão para impedir que o suplício continuasse, mas não chegou a fazê-lo, porque o diabo do homem impunha medo, com toda aquela serenidade radiosa da fisionomia. Faltava cortar a última pata; Fortunato cortou-a muito devagar, acompanhando a tesoura com os olhos; a pata caiu, e ele ficou olhando para o rato meio cadáver. Ao descê-lo pela quarta vez, até a chama, deu ainda mais rapidez ao gesto, para salvar, se pudesse, alguns farrapos de vida.

Garcia, defronte, conseguia dominar a repugnância do espetáculo para fixar a cara do homem. Nem raiva, nem ódio; tão-somente um vasto prazer, quieto e profundo, como daria a outro a audição de uma bela sonata ou a vista de uma estátua divina, alguma coisa parecida com a pura sensação estética. Pareceu-lhe, e era verdade, que Fortunato havia-o inteiramente esquecido. Isto posto, não estaria fingindo, e devia ser aquilo mesmo. A chama ia morrendo, o rato podia ser que tivesse ainda um resíduo de vida, sombra de sombra; Fortunato aproveitou-o para cortar-lhe o focinho e pela última vez chegar a carne ao fogo. Afinal deixou cair o cadáver no prato, e arredou de si toda essa mistura de chamusco e sangue. (Assis, 1998, p.294-5)

Momento crucial do conto, que contrasta com "os hábitos discretos e sintéticos de Machado de Assis" segundo o justo dizer de Antonio Candido (1977, p.30), o trecho descreve passo a passo o espetáculo privado da agonia de um rato, sem poupar detalhes ao leitor. A descrição investe no pormenor, o que nesse caso implica o relato técnico da tortura, indicando cada movimento do algoz, cada parte do corpo do animal que vai sendo por ele extirpada, além da avaliação minuciosa das respectivas reações de prazer e dor. Com efeito, a força expressiva desses parágrafos está no fato de que o narrador compactua com o torturador o mesmo ritmo lento, acompanhando a crueldade morosa que visa 
tanto acabar com o rato quanto salvar, na medida do possível, "alguns farrapos de vida". Afinal, essa demora é precisamente o traço que distingue o tormento.

O suplício, explica Michel Foucault (1977), "é a arte de reter a vida no sofrimento, subdividindo-a em mil mortes e obtendo, antes de cessar a existência, the most exquisite agonies. O suplício repousa na arte quantitativa do sofrimento". A definição, que tem por base registros judiciários anteriores ao século XIX, cabe perfeitamente para a cena do conto de Machado, uma vez que ela supõe a prática da tortura, não como expressão extrema ou descontrolada de raiva, mas efetivamente como técnica. Trata-se, pois, de ato racional, que obedece a um controle calculado e a uma regulação específica. Assim como nos cerimoniais da pena analisados pelo autor de Vigiar e punir, a ação de Fortunato tem por objetivo "produzir uma certa quantidade de sofrimento que se possa, senão medir, ao menos apreciar, comparar e hierarquizar" (Foucault, 1977, p.34).

Nesse sentido, a passagem difere em essência de outras do mesmo conto, nas quais o caráter sádico do personagem já está sugerido, mas de forma equívoca. Tomem-se, por exemplo, aquelas coincidências que aproximam os dois amigos, remontando, segundo o narrador, “à origem da situação". Primeiro, o encontro no teatro, ocasião que permite a Garcia contemplar o singular interesse de Fortunato por um "dramalhão cosido a facadas", e verificar que o sujeito abandona a plateia sem mais quando a trama se rende ao expediente da farsa. Depois, ao seguir o desconhecido pela rua, vendo-o parar às vezes "para dar uma bengalada em algum cão que dormia". Por fim, no socorro a um ferido, quando Fortunato - a se crer nas aparências, movido por "rara dedicação" - serve "de criado, segurando a bacia, a vela, os panos, sem perturbar nada, olhando friamente para o ferido, que gemia muito" (Assis, 1998, p.289).

Qual seria, vale perguntar, a grande diferença entre essas cenas e aquela do castigo do rato? Ou ainda: as primeiras passagens já não deixam clara a motivação do futuro sócio de Garcia? É bem provável que sim, mas a brevidade das descrições não autoriza o leitor a tirar nenhuma conclusão. Aí reside o "x" do problema. Isso ocorre até mesmo quando, mais tarde, o narrador conta que "o homem ocupava-se nas horas vagas em rasgar e envenenar gatos e cães": apesar dos verbos empregados, de patente afinidade com a sevícia, a frase é introduzida com a atenuante supostamente científica de que "Fortunato metera-se a estudar anatomia e fisiologia". Razões da ciência ou da perversão? Permanece a dúvida, pois sem a descrição detalhada não há como tomar conhecimento do sadismo naquilo que talvez lhe seja mais próprio: o prazer.

$\mathrm{O}$ escritor, nesse caso, parece não ter escapatória: ou registra o acontecimento em detalhe, capturando-lhe o sentido, ou perde o principal. O tema, aqui, impõe a forma. Não são poucas as implicações dessa exigência, a começar pela exclusão de um expediente literário relevante como a elipse narrativa que, de modo geral, corresponde ao gesto de encobrir tudo aquilo que quebraria o decoro da representação, sejam quais forem tais limites. ${ }^{4}$ Para criar um efeito de 
verdade, o teatro do tormento não pode apenas sugerir ou se manter no registro do subentendido. Faz-se necessária a exposição completa dos pormenores: o detalhe se impõe e ganha a cena.

Isso nos incita a pensar que talvez não seja arbitrário o hábito de se aludir a "cenas" de tortura, como se o encontro fortuito que acontece na língua desvelasse uma relação de base entre o tormento e o espetáculo. Ou, para evocar os termos de Artaud, como se toda crueldade fosse no fundo predestinada ao teatro. Poderíamos, então, concluir que a descrição de um suplício supõe necessariamente uma mise-en-scène, contando até mesmo com a participação de espectadores?

Tudo leva a crer que sim. Daí que, para entender o que está em jogo nesse trecho do conto, é pertinente convocar a conhecida oposição entre "narração sumária" e "apresentação cênica", pela qual se distingue o ponto de vista do narrador: na primeira, os feitos são referidos de forma concisa; na segunda, a maneira de apresentar cede ao detalhe, apostando o mais possível na particularidade. Percebe-se que o narrador machadiano, tendo se valido da narração sumária nos primeiros acontecimentos que insinuam o caráter de Fortunato, fica obrigado a mudar de estratégia quando decide passar do sugestivo ao afirmativo. A apresentação cênica lhe faculta essa possibilidade, autorizando-lhe um ponto de vista mais vertical, denso e, por certo, mais impiedoso.

Do mesmo modo, a distinção entre mimese e diegese - ou, dito à moda inglesa, entre showing ou telling - pode auxiliar a quem deseja penetrar nos bastidores do insólito teatro de Fortunato. ${ }^{5}$ Ora, ainda que a "cena" literária nunca seja literal - tecida por palavras, ela sempre depende da imaginação do leitor -, não há dúvidas de que, aqui, o mostrar (show) tende a prevalecer sobre o contar (tell). Com efeito, o narrador do conto define o ângulo, a distância e as modalidades do olhar que constroem o indigesto espetáculo, oferecendo a sua versão do ocorrido por meio de uma montagem entre elementos de forte apelo visual. Valendo-se da câmera lenta, que maneja com habilidade, ele disseca os fatos e os feitos diante de seu leitor.

A precisão cirúrgica do narrador não é, pois, menos notável do que aquela empregada pelo algoz ao retalhar o animal. Aliás, de tal forma se identificam um e outro que o primeiro chega a reconhecer no segundo um tipo de fruição que é própria dos escritores e artistas: "alguma coisa parecida com a pura sensação estética". Como já foi sugerido, é precisamente dessa identidade que nasce o conhecimento de causa, não importa quão secreta possa ser essa mesma causa.

3

Sem cumplicidade com o carrasco, não há como tocar o coração do terror - conclusão arriscada, por certo, uma vez que permite aproximar o autor de Dom Casmurro do controverso criador de Justine. Afinal, se o ponto de vista dos narradores sadianos sempre coincide com a consciência de seus pérfidos libertinos, o que ocorre no conto de Machado não difere muito desse modelo. 
Em Sade, sabemos, proliferam as descrições de torturas. Desnecessário lembrar que, neste caso, o investimento nas particularidades assume o centro das narrativas: os prodigiosos excessos e os fabulosos requintes a que se permitem os personagens lascivos se manifestam invariavelmente nos pormenores, atestando sua aposta radical na variedade, seja de corpos, de prazeres ou de perversões. Nas 120 journées de Sodome - livro que o marquês designa por vezes como "antologia dos gostos" -, encontra-se uma inesgotável fonte de exemplos, a reiterar que o parentesco entre a crueldade e o teatro só se fortalece quando o detalhe entra em cena.

Inspirados na paixão assassina de número 128 , os quatro senhores do castelo de Silling se abandonam a uma vertiginosa sessão de suplício sobre o corpo de jovem súdita. Descreve o narrador:

descarnam-lhe os ossos, serrando-os em diversos lugares, depois expõem os nervos em quatro pontos, como que formando uma cruz, amarram cada extremidade a um torniquete e passam a girá-lo de forma a esticar esses nervos que, sendo partes delicadas do corpo, provocam dores incríveis. Dão-lhe uma trégua para que, recuperando as forças, ela possa sofrer ainda mais, e retomam a operação, dessa vez esfolando os nervos com um canivete à medida que vão sendo estirados. Feito isso, abrem-lhe um buraco na goela, pelo qual fazem passar sua língua; queimam-lhe a mama restante em fogo brando [...] rasgam-lhe a bolsa do estômago. Em seguida, concentram-se no rosto: cortam-lhe as orelhas, queimam-lhe o interior do nariz, cegam-na derramando-lhe nos olhos cera fervente da Espanha, retalham-lhe o crânio, penduram-na pelos cabelos amarrando pedras em seus pés, de forma que ela caia e o crânio seja arrancado. (Sade, 1986, p.437-8)

Fiquemos por aqui. Mas não sem antes dizer que, apesar de todos esses excessos, o relato do sangrento ritual ainda continua por muitas linhas, obedecendo a uma vertiginosa progressão, sempre com o cuidado de observar que a vítima "ainda respira". Assim como o conto de Machado, os romances de Sade deixam transparecer um pacto entre o narrador e o carrasco, ambos empenhados na multiplicação dos pormenores que visam manter, na criatura imolada, "alguns farrapos de vida".

Atividade exemplar do suplício libertino, a dissecação de corpos vivos revela o interesse que os devassos têm em retardar o momento da morte. Cabe ao algoz a prorrogação indefinida do instante que antecede o último sopro do agonizante. Entende-se por que, tanto para o libertino francês quanto para o médico amador carioca, não basta apenas executar a vítima: é preciso que a morte seja efetivamente encenada por um corpo e, ainda, que cada ato dessa encenação seja reiteradamente conferido, apreciado e avaliado por ele, pois é dessa volúpia da aferição que ele tira não só o seu gozo, mas também a sua filosofia. Do ponto de vista do carrasco, a morte deve ser rigorosamente demonstrada.

Gilles Deleuze (1983, p.21) sustenta que a obra sadiana se organiza a partir de um intento puramente demonstrativo. Daí o equívoco, diz ele, de se supor que o sádico tenha alguma intenção pedagógica, como tantos presumem. 
O que está em jogo é algo completamente diferente: "não se trata nem mesmo de mostrar a alguém, mas de demonstrar, de uma demonstração que se confunde com a solidão perfeita e a onipotência do demonstrador". Sob esse prisma, a função demonstrativa seria, em si, um ato de violência, mas essa violência nada tem em comum com a emoção, sendo invariavelmente exercida a sangue frio, "com todo o seu rigor, toda a sua serenidade, toda a sua calma" (ibidem). Com toda a sua apatia, poderíamos acrescentar, já que a palavra remete a uma tópica essencial da libertinagem sadiana. ${ }^{6}$

Dessa apatia, que produz a frieza necessária aos seus propósitos perversos, o sádico retira um prazer tão intenso quanto exclusivo. Como propõe Deleuze, cada libertino raciocina dentro do círculo absoluto de seu egoísmo e, mesmo quando compartilha o raciocínio com seus comparsas, ele jamais rompe essa solidão primordial. O prazer da demonstração é solitário, onipotente, inviolável. $\mathrm{Ou}$, se preferirmos a fórmula machadiana: trata-se de um prazer "vasto, quieto e profundo".

Dominante no sadismo, a exigência de demonstração subordina por completo o imperativo da descrição. Embora indispensáveis, até mesmo por seu poder de provocação, as reiteradas e minuciosas encenações de martírios nada mais são que ilustrações sensíveis de um conceito abstrato. $O$ fator descritivo, destinado a expor os gostos particulares do sádico quando detalha suas violências prediletas, representa apenas um elemento pessoal, que estaria sujeito a um fator anônimo, a lei soberana da crueldade. Valendo-se dessa chave, Deleuze (1983, p.22) propõe o sadismo como a identificação dessa violência com "uma Idéia da razão pura, com uma demonstração capaz de subordinar a si o outro elemento".

Nada difícil associar essas palavras, originadas da leitura dos textos de Sade, ao relato da agonia do rato, tal como se oferece no conto de Machado. Nesse também a apresentação cênica parece subordinada à razão demonstrativa, como que dramatizando um ditame superior: não por acaso, é onipresente a metáfora do laboratório, onde a experiência concreta está sempre a serviço de uma ideia abstrata. Ademais, o narrador evoca amiúde tópicas da medicina, a começar da menção aos estudos de anatomia empreendidos pelo "médico amador" até chegar ao tema forte da dissecação, ambos destinados a demonstrar como funcionam, vivem e morrem os corpos. Tópicas científicas, pois, que supõem um franco deslizamento do plano individual para o impessoal, e que nos incitam a interrogar de novo o título do conto: como então sustentar que a causa secreta fica esclarecida por completo quando Garcia e o leitor tomam conhecimento dos gostos pessoais de Fortunato?

É bem verdade que, logo depois de testemunhar a tortura, o jovem médico tenta interpretar a estranha volúpia do sócio, confidenciando a si mesmo: "castiga sem raiva, pela necessidade de achar uma sensação de prazer, que só a dor alheia lhe pode dar: é o segredo desse homem". Todavia, ainda que o juízo 
de Garcia deva estar correto, isso não significa que "o segredo desse homem”, uma vez desvelado, coloque um ponto final no mistério ironicamente anunciado no título. Aliás, a se crer na tese de Deleuze, a causa secreta não pode mesmo se resumir a essa cena, nem a nenhuma outra, uma vez que ela implica uma ideia pura do Mal - ou, se quisermos, uma negação pura -, impossível de conformarse a qualquer particularidade. Nesse sentido, Fortunado e Dolmancé são irmãos de sangue e obedecem à mesma lei.

Machado avec Sade? - a conclusão é tentadora, mas pode ser apressada. Ainda que seja possível traçar aproximações convincentes em torno da razão demonstrativa, as afinidades entre os dois autores não avançam muito além disso. Basta comparar as imagens de tortura concebidas por cada escritor para que se percebam diferenças fundamentais entre ambos.

Para tanto, é preciso olhar mais de perto para cada cena. Típica da ficção sadiana, aquela das 120 journées prima por um imaginário do excesso que, obviamente, se traduz em excesso verbal: os ossos são descarnados e serrados, os nervos expostos, estirados com um torniquete e esfolados com um canivete; a garganta é perfurada, a língua retirada e esticada; a mama - sublinha o narrador: "restante" - é queimada, as entranhas vasculhadas, o estômago rasgado, as orelhas cortadas, as narinas queimadas, os olhos derretidos, o crânio retalhado e arrancado, tudo isso com a vítima ainda viva, e assim por diante. A sequência de imagens é de tal forma vertiginosa que, conforme vai acumulando crueldades, também vai perdendo qualquer sentido de realidade, até se tornar francamente irreal. A partir de certo momento, a tortura se desenvolve como que obedecendo a uma lógica própria, sujeita tão somente à fantasia da multiplicação.

De fato, toda aventura libertina responde a um desejo ilimitado de expansão. Trata-se sempre de abarcar as maiores quantidades, de alcançar os marcos inatingíveis, de ultrapassar a derradeira conquista. Valendo-se desses expedientes, a razão sadiana caminha em paralelo à insaciabilidade de seus devassos, subordinada ao mandato de ocupar todos os espaços vazios. Daí o privilégio dado às multiplicações, mesmo quando o objetivo é dar conta do que foi dividido, desmembrado ou subtraído. Assim sendo, convictos de que "um excesso sempre conduz ao outro", os personagens de Sade não concebem nenhum sinal de esgotamento ou saturação em seu horizonte, mas simplesmente a manutenção de sua singular produtividade. Dito de outra forma: nesse caso, o excesso trabalha o tempo todo para a manutenção do excesso. ${ }^{7}$

Entende-se por que Deleuze $(1983$, p.30) vai interpretar a obra do marquês como "a negação em toda a sua extensão, em toda sua profundidade", mas não sem enfatizar que se trata aí de uma "idéia delirante de negação". Com justa razão, uma vez que, em Sade, todo e qualquer argumento, por mais racional que seja, acaba sendo arrastado pela fantasia, e de forma tal que termina por se oferecer ao leitor como uma alucinação. O próprio intento de violência 
que preside a cena libertina está sempre à mercê dessa exigência de fabulação, confirmando a centralidade do "delírio da razão" que se percebe no autor. Ora, será precisamente esse traço a marcar a distinção capital entre a literatura sadiana e o conto de Machado.

Tome-se de novo a cena do rato. Passada num austero gabinete, em tudo diverso das lúbricas alcovas do deboche, ela mais se assemelha a um experimento de laboratório. Quase tudo ali é medido e, de certa forma, comedido. Fortunato corta, uma a uma, as patas do rato e, cada vez que o faz, desce "o infeliz" até a chama que sobe do prato à sua frente. Extirpada a quarta pata, faz o mesmo com o focinho do animal, aproximando-o pela última vez do fogo, até por fim deixar cair o cadáver. Escusado observar a distância que separa a sóbria descrição machadiana das vertiginosas cerimônias de tortura das 120 journées de Sodome. Contudo, uma tal economia na imaginação da crueldade é amplamente compensada em outro plano. A passagem esbanja notações sobre sensações e sentimentos: Garcia fica "horrorizado" com o que vê, Fortunato experimenta "delícias", enquanto “o miserável animal estorcia-se, guinchando, ensanguentado, chamuscado, e não acabava de morrer”.

Fica patente, nessa comparação, a distância entre uma literatura que trabalha fundamentalmente com tipos - encarnações de absolutos, como acontece com quase todos os protagonistas da ficção libertina do setecentos francês - e outra voltada para a particularização de personagens pela via da profundidade psicológica, tal como encontramos nos grandes escritores realistas do século XIX. Nesse sentido, embora obedeçam à mesma lei secreta, Dolmancé e Fortunato pertencem a famílias distintas.

O primeiro encarna, de forma exemplar, a figura do devasso de Sade, ostentando um tal gosto pelo mal que não deixa nenhuma sombra de ambivalência acerca de seu caráter: "é o mais célebre ateu, o mais imoral dos homens... É a corrupção em pessoa, na sua forma mais extrema e completa, o indivíduo mais celerado e cruel que possa existir no mundo" (Sade, 1976, p.41). Já o segundo é, antes de tudo, um sujeito dissimulado: instado a apresentar-se logo no início da narrativa, ele declara sumariamente chamar-se "Fortunato Gomes da Silveira, ser capitalista, solteiro, morador do Catumbi”, sempre se valendo de sua situação social favorável para posar como homem de bem, embora mantenha hábitos escusos no silêncio da intimidade (Assis, 1998, p.289). Em suma, apesar de compartilharem a mesma forte inclinação pelo mal, os personagens em questão não são intercambiáveis, e muito menos as cenas que protagonizam.

Valeria o mesmo para as suas vítimas?

A questão é ardilosa. Ainda que a primeira impressão recaia sobre o fato de que elas não partilham o pertencimento à mesma espécie, isso talvez seja pouco relevante, posto que nas mãos de seus respectivos carrascos tanto o rato quanto a jovem ficam reduzidos à mera condição de objetos. Se os algozes aqui estão subordinados à modulação dos textos - o delírio libertino, no caso de Sade, 
e o realismo psicológico, no de Machado -, as vítimas passam ao largo dessas diferenças formais, permanecendo em uma posição passiva e fixa, que as torna praticamente iguais e intercambiáveis. Uma vez nessa posição, sob o cutelo dos senhores, ratos e seres humanos são a mesma coisa.

Ou quase: ainda que as vítimas não possam ser discerníveis por suas qualidades intrínsecas, e muito menos pela posição que ocupam, alguma coisa separa o roedor machadiano da súdita de Silling. Esse diferencial se faz notar justamente quando atentamos ao efeito de realidade produzido por cada uma das passagens. Lançados à vertigem da imaginação, os tormentos descritos por Sade se inscrevem na ordem do inconcebível: pertencem a um mundo outro, comandado pelas leis da fantasia e, em certo sentido, alheios à humana condição. As cenas sadianas sempre transcorrem em lugar incógnito e, sobretudo, sem a menor garantia de veracidade. Por isso mesmo, embora sejam protagonizados por homens e mulheres, os suplícios do deboche perdem em humanidade se comparados ao perverso castigo do animal.

A assustadora cena desvelada em "A causa secreta" pertence ao nosso mundo e, como tal, se mostra passível de acontecer com qualquer um de nós, rato ou pessoa. Se podemos nos reconhecer nela, é porque seus personagens carregam essa "parecença com o humano" que, segundo José Luiz Passos (2007, p.42), traduz a "visão convincente do modo como modernamente nós nos concebemos como pessoas", marca distintiva dos romances de Machado. Daí, portanto, que o sadismo de Fortunato venha a ser bem mais verossímil do que as inconcebíveis fabulações de crueldade dos insaciáveis celerados de Sade. Daí também que seja mais fácil devotar compaixão ao pobre rato imolado do que à imponderável legião de corpos sacrificados à volúpia libertina.

Se, como queria Jean-Jacques Rousseau, a compaixão estiver de fato na origem do reconhecimento entre os homens, sendo o sentimento fundador da noção de "semelhante", não surpreenderá se o leitor do conto, comovido com a desgraça do infeliz, venha a transformá-lo em seu foco privilegiado de identificação. E, quem sabe, venha até a declarar afeto por esse animal que goza de pouca simpatia na espécie humana, reiterando a imprevista e desconfortável aproximação manifesta pelo personagem de Dom Casmurro: "Amo o rato". 8

5

Humano e terrível, o suplício concebido em "A causa secreta" ainda supõe uma diferença crucial se comparado às liturgias do deboche: rompendo com a invariável dupla que estrutura toda a ficção do marquês, o narrador machadiano introduz um terceiro elemento para perturbar a harmonia do tenebroso rito a dois. Entre o carrasco e sua vítima, vem se interpor então um observador.

Todas as cenas que implicam o sadismo de Fortunato são rigorosamente observadas por seu sócio. Seja no espaço público do teatro ou da rua, seja na privacidade do gabinete, o ato de crueldade nunca fica restrito ao par algoz/vítima, oferecendo-se também ao olhar sempre curioso do jovem médico. Além disso, 
não é apenas a presença empírica que faz de Garcia o espectador privilegiado das práticas do amigo, mas igualmente o fato de que ele empresta seu ponto de vista ao narrador. Como observa Silviano Santiago (no prelo, p.11), conforme o conto avança, o leitor

passará às mãos de uma terceira pessoa falsa, já que a perspectiva sobre fatos e personagens lhe será fornecida por Garcia e, na maior parte dos parágrafos restantes, apenas pela visão dele. Em outras palavras, o narrador é onisciente, mas o ponto de vista passou a ser selecionado, controlado e restrito.

Sob essa óptica, o médico manifesta uma imprevista, mas possível, solidariedade com o sádico do Catumbi. Ademais, sendo a narração conduzida segundo a sua consciência, é ele então quem partilha aquela identidade de base entre o algoz e o narrador de seus atos, ambos condenados ao imperativo do detalhe. A hipótese é arriscada e merece investigação mais demorada.

Sempre atenta às ações de Fortunato, na dupla posição de testemunha e de eminência parda da narração, a figura de Garcia obriga o leitor a rever o lugar de Maria Luísa na economia do texto. Uma leitura mais cuidadosa vem mostrar que a doce jovem de "olhos meigos e submissos" ocupa o tempo todo o lugar de vítima, aqui também expresso por meio da tópica sadiana dos "infortúnios da virtude". 9 As descrições da personagem se valem não raro de adjetivos como desconsolada, fraca, aflita, sendo ela definida como "criatura nervosa e frágil", cuja "solidão moral era evidente", sobretudo por conta da relação com o marido, fundada "na resignação e no temor". Não surpreende que lhe seja negado um ponto de vista próprio, e que, no limite, sua situação a aproxime bastante do rato de Fortunato e dos súditos de Silling.

Uma tal constatação vem adensar a suspeita de um elo mais profundo entre os sócios, o que induz a uma releitura da frase que descreve o estreitamento de amizade entre os dois homens: “a comunhão de interesses apertou os laços de intimidade" (Assis, 1998, p.293). Haveria então algum outro motivo a fortalecer essa relação, para além do fato já nada desprezível de que a profissionalização do médico recém-formado só se realiza pela mediação do capital que Fortunato gentilmente lhe oferece? Que outra sorte de contrato legitimaria essa associação?

Ainda que o conto não nos autorize a dar uma resposta definitiva a tais questões, é preciso atentar para a passividade que recobre a pessoa de Garcia, em especial na terrível agonia do rato. Sua inércia salta aos olhos. Assim como acontece com o viajante estrangeiro da novela $\mathrm{Na}$ colônia penal, de Kafka, o médico não esboça nenhum gesto, por mínimo que seja, para impedir o martírio do qual é a testemunha privilegiada. ${ }^{10}$ Apesar de "horrorizado" com a cena, o medo o impede de intervir no processo, permitindo que a tortura seja executada do começo ao fim, tal qual um espetáculo que lhe oferece "the most exquisite agonies".

Espetáculo eminentemente privado, deve-se sublinhar, cujo cenário é uma próspera e recatada casa de família burguesa. Não seria então o caso de se associar essa evidência à tese foucaultiana de que os cerimoniais do suplício desapare- 
ceram do âmbito público a partir do século XIX, tornando-se ritos cada vez mais reservados a espaços interiores e íntimos? ${ }^{31}$ Essa é uma possível chave de leitura para a cena da vivissecção do animal, uma vez que ela se desenrola num laboratório doméstico, para onde Fortunato havia transferido seus experimentos, já que os guinchos dos animais imolados "atordoavam os doentes" de sua clínica. Tudo, ou quase tudo, conduz a uma ideia de privatização do tormento que, além de confirmar a tese histórica de Foucault, supõe ainda o primado do mal como fator invariável da condição humana. Maldade primordial que, não podendo ser expiada em público, reaparece com igual força no âmbito da privacidade.

Espetáculo secreto, portanto, transferido para o interior da casa e, muito provavelmente também, para a intimidade da alma. Desnecessário dizer que essa nova disposição do teatro dos suplícios está relacionada à emergência de um tipo particular de voyeurismo, próprio da sensibilidade moderna. Nessa cerimônia reservada, o face a face entre observador e observado associa, sem nenhuma mediação, a fruição de quem pratica e aquela de quem vê. A exemplo de Garcia, esse discreto voyeur se define menos pelo que faz do que por aquilo que não faz, convicto de que a intimidade preserva sua reputação e a distância lhe garante $o$ salvo-conduto. Trata-se, tão somente, de "apreciar" o sofrimento alheio.

Por tal razão, ganha relevo a notável inversão de papéis que fecha o conto, promovendo uma inesperada troca de lugares entre Garcia e Fortunato. Morta a pobre Maria Luísa, pouco tempo depois do esquartejamento do rato, os dois amigos se defrontam no velório. Tendo o viúvo se ausentado durante duas horas, o jovem médico contempla o defunto por alguns instantes, beijando-o na testa. Nesse momento, Fortunato retorna e assiste à cena:

Estacou assombrado; não podia ser o beijo da amizade, podia ser o epílogo de um livro adúltero. Não tinha ciúmes, note-se; a natureza compô-lo de maneira que não lhe deu ciúmes nem inveja, mas dera-lhe vaidade, que não é menos cativa ao ressentimento. Olhou assombrado, mordendo os beiços.

Entretanto, Garcia inclinou-se ainda para beijar outra vez o cadáver; mas então não pôde mais. $\mathrm{O}$ beijo rebentou em soluços, e os olhos não puderam conter as lágrimas, que vieram em borbotões, lágrimas de amor calado, e irremediável desespero. Fortunato, à porta, onde ficara, saboreou tranqüilo essa explosão de dor moral que foi longa, muito longa, deliciosamente longa. (Assis, 1998, p.297)

É Fortunato, agora, o voyeur da história. Percebe-se, contudo, que a nova posição não rouba ao homem, "faminto de sensações", nenhuma migalha de sua insaciável capacidade de desfrutar da dor alheia. Ao contrário, nessa condição ele parece tão confortável quanto naquela que o caracterizara até então, fruindo a distância com uma intensidade tal que produz, sem nenhum prejuízo, o potente "reflexo da alma satisfeita" antes observado pelo narrador. Assim, apesar da troca de papéis, o sádico se mantém exatamente no mesmo lugar. O mesmo acontece com a vítima, mais que nunca ostentando sua mera condição de objeto. Restaria, portanto, interrogar a figura de Garcia quanto à qualidade do gozo que experimenta nessa mórbida circunstância. 
Machado, porém, não nos oferece elementos para resolver mais essa charada. Em vez disso, a derradeira cena compõe um novo quadro vivo, a recolocar de outra forma, mas com igual intensidade, a questão daquela "coisa grave e feia" que reúne os três personagens. Ou, se quisermos, a recolocar o problema de uma "causa secreta" que, definitivamente, não se esgota no ostensivo tormento do rato. Embora o episódio solucione a charada inicial, o segredo do título fica em suspenso no final do conto, retornando para as mãos daquele oscilante narrador machadiano que, sendo pouco confiável, será menos ainda nessa enigmática história.

Com efeito, ainda que mantenha a hierarquia inicial, a nova gramática dos olhares, instaurada na cena do velório, repõe a questão do ponto de vista. Santiago (no prleo) propõe que, no desfecho, o narrador em terceira pessoa opera significativa mudança, privilegiando não mais a perspectiva do médico, mas aquela de seu estranho sócio. Para o crítico, o que ocorre então é uma nova troca de sinais, que vem passar a narração para o controle do sádico: "revelado o segredo de Fortunato pelos olhos de Garcia, havia que se revelar o de Garcia pelos olhos de Fortunato" (Santiago, no prelo, p.23). Será mesmo?

Chegaríamos a conclusões distintas se uma outra hipótese, também plausível, fosse aventada: a de que Garcia mantém o comando da consciência do narrador até a última linha. Não se deve ignorar que o principal alvo da narração continua sendo Fortunato, cujos prazeres rendem comentários bastante semelhantes nos dois momentos: à "delícia íntima das sensações supremas" observada na tortura do laboratório doméstico, por exemplo, vem se somar a contemplação "deliciosamente longa" do velório, a indicar um mesmo olhar de reconhecimento em ambas as cenas. Cabe ao narrador, portanto, a apreciação rigorosa da qualidade do gozo sádico, anotando seus ínfimos detalhes e suas múltiplas derivações, entre as quais se inclui em particular o deleite do voyeur. Em suma, há indícios convincentes de que ainda é Garcia quem serve de guia ao narrador, fazendo desse um observador minucioso de seu malvado sócio.

Se assim for, o leitor terá diante de si um a persona homem desesperado e íntegro, que só no momento-limite deixa entrever a paixão contida pela mulher do amigo, revelada no casto beijo que oferece à morta, molhado de lágrimas e talvez de arrependimento. Melodramático e trágico, como aliás costumam ser os "epílogos dos livros adúlteros", o final ainda contrasta a dor moral do médico com o funesto prazer do novo voyeur, descrevendo com propriedade as sensações que o deliciam. $\mathrm{O}$ tom de censura encobre, quase que por completo, $\mathrm{o}$ conhecimento de causa. Como resultado, temos um desfecho em tom edificante, por certo condizente com tal narrador, mas na verdade pouco provável num autor tão avesso a conclusões bem-intencionadas.

$\mathrm{O}$ que se ocultaria então nos meandros do discurso humanitário e edificante desse intrigante narrador? Não seria talvez aquela coisa sem nome, grave e feia? E não poderia ser, essa coisa impronunciável, justamente a conivência 
silenciosa do voyeur, a quem cabe uma estranha ciência do prazer vasto, quieto e profundo que o algoz experimenta? Não há como sabê-lo. Impossível conhecer a fundo a misteriosa motivação humana para a crueldade. A causa, que viria a explicar a remota origem do mal no coração dos homens, permanece fechada em seu inviolável segredo.

\section{Notas}

1 Este texto foi apresentado em versão reduzida na mesa-redonda "As causas secretas: o mal em Machado de Assis", do Sexto Congresso Internacional da American Portuguese Studies Association (Apsa), realizado em outubro de 2008 na Yale University, New Haven (EUA), e publicado originalmente no dossiê consagrado a Machado de Assis, organizado pelo Dr. Pedro Meira Monteiro para a Luso-Brazilian Review, 46.1 (The University of Wisconsin Press, 2009).

2 Agradeço ao autor a gentileza do envio de seu ensaio inédito sobre o conto, e a Hélio Seixas Guimarães a informação e intermediação desse contato. Sua leitura foi fundamental para o desenvolvimento das reflexões aqui contidas.

3 Vale aqui reiterar o advérbio "aparentemente" e remeter de novo ao ensaio de Silviano Santiago (no prelo), o qual analisa em profundidade cada passo do conto, provando que ele realmente não contém nada de simples ou de mera gratuidade romanesca.

4 A propósito da questão do decoro como motivo de uma elipse, lembra Ismail Xavier (2003, p.65-75) que "a história do teatro traz dados sintomáticos, como o referente à forma como se evitava a apresentação cênica da violência na tragédia clássica, gênero em que os assassinatos aconteciam off stage, em contraste com o que acontecerá bem mais tarde nas peças de Shakespeare, cujas regras de bom gosto e decoro admitiam o ato de violência e o assassinato executado diante do olhar da platéia. No teatro popular moderno, e principalmente no cinema, essa possibilidade se tornou rotina, e lutas corporais, mortes e, mais recentemente, o sexo, ganharam legitimidade como acontecimentos visíveis no palco ou na tela. Isso, evidentemente, está longe de ter eliminado a discussão dos limites, dos motivos e das circunstâncias que separam o aceitável do proibido, conforme o contexto social em que o debate se dá".

5 Para um aprofundamento do tema, ver o artigo Segre (1989, esp. p.65).

6 Desenvolvi o tema em Sade - A felicidade libertina (Moraes, 1994, p.198-202).

7 Desenvolvi o tema em "Inventário do abismo" (Moraes, 2006, p.9-12).

8 Cumpre contextualizar a frase, proferida por Bentinho ao declarar sua "simpatia ao rato": "Não me pesa dizê-lo; os que amam a natureza como ela quer ser amada, sem repúdio parcial nem exclusões injustas, não acham nela nada inferior. Amo o rato, não desamo o gato" (Assis, 1986, p.917).

9 Lembra Silviano Santiago (no prelo, p.15) que “o perfil psicológico da frágil esposa de Fortunato não destoa de outras mulheres casadas - e em busca de carinho e proteção - no universo senhorial e machista da ficção machadiana". Ainda que, de forma geral, se possa concordar com essa afirmação, não se deve esquecer de que uma das principais características das heroínas de Machado é a dissimulação, como bem mostra José Luiz Passos (2007, p.58-78) em seu consistente ensaio. Isso nos permite questionar a identidade entre Maria Luísa e Conceição de "Missa do Galo", tal como propõe Santiago, 
uma vez que a primeira realmente encarna todos os traços da mulher vitimada pelo poder senhorial, enquanto a segunda só é resignada nas aparências, posto que sabe muito bem disfarçar seus verdadeiros sentimentos, para benefício próprio. Prova disso é dada pelos destinos reservados a cada uma das personagens, que são radicalmente opostos.

10 Pode ser produtiva a comparação entre o médico de "A causa secreta" e o viajante da novela Na colônia penal, de Kafka (1998, p.42): em ambos os casos, o leitor tem diante de si personagens supostamente "esclarecidos", cosmopolitas, civilizados, de escolaridade alta, que deixam clara sua posição contra os atos cruéis. Michael Wood (2005, p.88-91) chama a atenção para o fato de o estrangeiro kafkiano ser convidado a "ler" a punição imposta ao condenado, já que tal leitura exige espectadores bem letrados e capazes de "decifrar", como quer o oficial, aquela refinada escrita. De fato, mesmo sem dar conta da tarefa, o explorador prova que reúne essas qualidades ao reconhecer que se trata de um processo "muito engenhoso". Assim também, Jeanne-Marie Gagnebin (2006, p.124) insiste que "oficial e viajante tratam-se mutuamente como dois parceiros iguais": embora não concordem entre si, são capazes de manter um diálogo civilizado em francês, língua que distingue a burguesia culta da época, sendo inacessível ao tosco soldado que acompanha o trabalho e ao miserável condenado. No limite, diz a ensaísta, ainda que o cultivado visitante tome partido contra a máquina, "seu interlocutor natural só pode ser o oficial". Por certo, essas leituras apostam na conivência entre o carrasco e seu espectador, confirmada pelo fato de que o viajante nada faz para intervir no suplício.

11 Não seria igualmente o caso de se recordar que, segundo Foucault (1977, p.16-20), essa mudança se efetiva quando, em nome de uma "humanização" da morte, "um exército inteiro de técnicos veio substituir o carrasco, anatomista imediato do sofrimento"? E que, dentro desse exército, a figura do médico ocupou desde o início um lugar especial? Eis aí uma possível chave para se compreender a centralidade da medicina na trama do conto, dada tanto pela atividade dos personagens - um na qualidade de profissional, o outro na irônica condição de "amador" -, quanto pela ocorrência de vários episódios de sadismo em torno a questões médicas.

Referências bibliográficas

ASSIS, M. de. Dom Casmurro. In: __. Obra completa. Rio de Janeiro: Aguillar, 1986. v.1.

A causa secreta. In: Contos - uma antologia. Seleção e organização de John Gledson. São Paulo: Cia. das Letras, 1998. v.2.

BACHELARD, G. Lautréamont. Trad. Maria Isabel Braga. Lisboa: Litoral, 1989.

BARTHES, R. Sade, Fourier, Loiola. Trad. Maria de Santa Cruz. Lisboa: Edições 70, 1979.

CANDIDO, A. Esquema de Machado de Assis. In: . Vários escritos. São Paulo: Duas Cidades, 1977.

DELEUZE, G. Apresentação de Sacher-Masoch. In: SACHER-MASOCH, L. von. A Vênus das peles. Trad. Jorge Bastos. Rio de Janeiro: Taurus, 1983.

FOUCAULT, M. Vigiar e punir - Nascimento da prisão. Trad. Ligia M. Ponde Vassallo. Petrópolis: Vozes, 1977. 
GAGNEBIN, J.-M. Escrituras do corpo. In: Lembrar, escrever, esquecer. São Paulo: Editora 34, 2006.

KAFKA, F. O veredito/Na colônia penal. Trad. Modesto Carone. São Paulo: Cia. das Letras, 1998.

MORAES, E. R. Sade - A felicidade libertina. Rio de Janeiro: Imago, 1994.

Inventário do abismo. Apresentação. In: SADE, D. A. F. (Marquês). Os 120

dias de Sodoma. Trad. Alain François. São Paulo: Iluminuras, 2006.

PASSOS, J. L. Machado de Assis, o romance com pessoas. São Paulo: Edusp, 2007.

SADE, D. A. F. (Marquês). La philosophie dans le boudoir. Paris: Gallimard, 1976.

Les 120 journées de Sodome. In :

Oeuvres complètes. Paris: Pauvert, 1986.

SANTIAGO, S. Solidariedade do aborrecimento humano. S. 1.: s. n., (no prelo).

SEGRE, C. Narração/narratividade. In: Enciclopédia Einaudi. Lisboa: Imprensa Nacional; Casa da Moeda, 1989. v.17: "Literatura - Texto".

WOOD, M. Kafka and the Third Reich. In: Literature and the taste of knowledge. Cambridge: Cambridge University Press, 2005.

XAVIER, I. Do texto ao filme: a trama, a cena e a construção do olhar no cinema. In: PELLEGRINI, T. et al. Literatura, cinema e televisão. São Paulo: Senac; Itaú Cultural, 2003.

RESUMO - A descrição da tortura de um rato, no conto "A causa secreta" de Machado de Assis, pode parecer tímida se comparada às cenas de suplício narradas por Sade. Todavia, uma leitura mais atenta encontrará ali as condições essenciais para a eclosão de uma misteriosa forma de prazer que costuma estar associada à figura do "sádico". Uma tal aproximação surpreende ainda mais quando se constata que o sadismo do protagonista do conto assume contornos bem mais verossímeis do que as inconcebíveis fabulações de crueldade dos devassos do marquês. Este texto parte do confronto entre os dois autores, valendo-se do diálogo entre uma dimensão estética (o realismo) e outra ética (o mal), na tentativa de propor uma interpretação do conto machadiano.

PALAVRAS-CHAVE: Machado de Assis, Marquês de Sade, "A causa secreta", Sadismo, Crueldade, Literatura brasileira.

ABSTRACT - The description of a mouse being tortured in Machado de Assis's short story "A causa secreta" [English translation: "The Secret Heart"] may seem timid if compared with the scenes of agony narrated by the Marquis De Sade. Nevertheless, a detailed reading will find in this short story essential conditions for the outburst of a mysterious form of pleasure that is usually associated with the image of a "sadist". A closer look might surprise the reader even more with the acknowledgement that the sadism of the protagonist takes on shapes that are more verisimilar than the inconceivable accounts of cruelty of the Marquis's dissolute characters. By means of a dialogue between an aesthetic dimension (realism) and an ethic dimension (evil), this essay confronts these two 
authors in an attempt to propose an interpretation of Machado de Assis's short story. KErWORDS: Machado de Assis, Marquis de Sade, "A causa secreta" ["The secret heart"], Sadism, Cruelty, Brazilian literature.

Eliane Robert Moraes é professora de Estética e Literatura na PUC-SP e no Centro Universitário Senac-SP. Autora de diversos ensaios sobre o imaginário erótico na literatura, também assina a tradução da História do olho, de Georges Bataille (CosacNaify, 2003). Publicou, dentre outros, os livros: Sade - A felicidade libertina (Imago, 1994), O corpo impossivel (Iluminuras; Fapesp, 2002) e Lições de Sade - Ensaios sobre a imaginação libertina (Iluminuras, 2006). @ - elianermoraes@uol.com.br

Recebido em 6.11.2008 e aceito em 5.12.2008. 